\title{
Exposure to biomass smoke as a risk factor for oesophageal and gastric cancer in low-income populations: A systematic review
}

\author{
Violet Kayamba ${ }^{1,4}$, Douglas C. Heimburger ${ }^{2,3}$, Douglas R. Morgan ${ }^{2,3}$, Masharip Atadzhanov ${ }^{4}$, \\ Paul Kelly ${ }^{1,4,5}$
}

1. Tropical Gastroenterology \& Nutrition Group, University of Zambia School of Medicine, Lusaka, Zambia

2. Vanderbilt Institute for Global Health, Vanderbilt University, Nashville, Tennessee, USA

3. Department of Medicine, School of Medicine, Vanderbilt University, Nashville, Tennessee, USA

4. Department of Internal Medicine, University of Zambia School of Medicine, Lusaka, Zambia

5. Blizard Institute, Division of Gastroenterology, Barts \& The London School of Medicine and Dentistry, London, United Kingdom

Correspondence: Dr Violet Kayamba (viojole@yahoo.com)

\section{Background}

\section{Abstract}

Upper gastrointestinal cancers contribute significantly to cancer-related morbidity and mortality in sub-Saharan Africa, but they continue to receive limited attention. The high incidence in young adults remains unexplained, and the risk factors have not been fully described.

Methods

A literature search was conducted using the electronic database PubMed. Beginning from January 1980 to February 2016, all articles evaluating biomass smoke exposure with oesophageal and gastric cancer were reviewed.

Results

Over $70 \%$ of the African population relies on biomass fuel, meaning most Africans are exposed to biomass smoke throughout their lives. Cigarette smoke is an established risk factor for upper gastrointestinal cancers, and some of its carcinogenic constituents are also present in biomass smoke. We found eight case-control studies reporting associations between exposure to biomass smoke and oesophageal cancer, and two linking biomass smoke to gastric cancer. All of these papers reported significant positive associations between exposure and cancer risk. Further research is needed in order to fully define the constituents of biomass smoke, which could each have varying specific and synergistic or independent contributions to the development of upper gastrointestinal cancers

Conclusions

Exposure to biomass smoke is an environmental factor influencing the development of upper gastrointestinal cancers, especially in low-resource settings.

\section{Introduction}

An estimated 3 billion people cook and heat their homes using biomass fuel obtained from animal or plant materials, such as wood, charcoal, dung, or crop residue. ${ }^{1}$ Worldwide, 4.3 million people are thought to die prematurely each year from illnesses attributable to biomass smoke exposure. ${ }^{2}$ Of these deaths, $12 \%$ are from to pneumonia, $34 \%$ from stroke, $26 \%$ from ischaemic heart disease, $22 \%$ from chronic obstructive pulmonary disease, and $6 \%$ from lung cancer. ${ }^{2}$ Upper gastrointestinal (UGI) cancers, particularly of the oesophagus and stomach, are yet to be listed among these diseases, but there is emerging evidence that exposure to biomass smoke may be contributing to the pathogenesis of these cancers. In this review, we look at available literature on the influence of biomass smoke exposure on oesophageal and gastric cancer.

\section{Upper gastrointestinal cancer epidemiology}

It has been estimated that global cancer incidence will nearly double by 2030, and that much of this increase will occur in low- and middle-income countries. Seven cancers account for $70 \%$ of the global cancer burden, and oesophageal cancer is the sixth most common cause of cancer death worldwide. $^{3}$ Most of the cases of oesophageal cancer occur in less developed countries, and it generally affects men more than women. The highest incidence rates for oesophageal cancer are in eastern Asia, at 17 per 100,000 per year in men, closely followed by southern Africa, with about

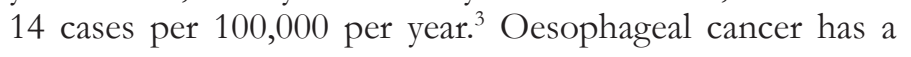

very poor survival, with the highest mortality rates being those for eastern Asia and southern Africa. Accurate data on oesophageal cancer from many African countries remain scanty, mainly due to a paucity of population-based registries in this region. ${ }^{4}$ Estimates for Africa rank oesophageal cancer as the fifth most common cancer among men and the ninth among women. In southern Africa, it is ranked third among men and fifth among women. ${ }^{5}$ The American Cancer Society reported the annual incidence rate for the whole of Africa to be 6.7 per 100,000 in men and 3.5 per 100,000 in women (with the highest incidence in southern Africa, at 22.3 per 100,000 for men and 11.7 per 100,000 for women). ${ }^{6}$ Particularly high rates have been reported in Kenya, Malawi, and the Eastern Cape province of South Africa. ${ }^{3}$

Gastric cancer is the fifth most common cancer globally and is third among the causes of cancer mortality. More than $70 \%$ of the cases of gastric cancer occur in developing countries, and like oesophageal cancer, it is more common in men than women. ${ }^{3}$ The highest age-standardised annual incidence rates are from eastern Asia, at 35.4 per 100,000 for men and 13.8 per 100,000 for women. The highest mortality rates are also from eastern Asia, with an estimated 24 and 9.8 per 100,000 for men and women, respectively. North America has the lowest mortality rates, at 2.8 and 1.5 per 100,000 for men and women, respectively. ${ }^{3}$ Similar to oesophageal cancer, data on gastric cancer from Africa are scarce. GLOBOCAN estimates suggest that the annual incidence of gastric cancer in Africa is 3.3 to 15.4 per 100,000 for men and 2.6 to 8.2 
per 100,000 for women. On the other hand, the American Cancer Society report on Cancer in Africa estimates that the annual incidence for southern Africa is 4.1 per 100,000 for men and 2.2 per 100,000 for women, making it the seventh most common cancer among men and eighth among women, respectively. ${ }^{6}$ In Africa overall, the incidence of gastric cancer is estimated to be lowest in West Africa, while high incidence clusters have been reported around the Great Lakes region, particularly western Uganda, and some parts of South Africa and Mali. ${ }^{5,7,8}$

\section{Domestic use of biomass fuel}

Humans have traditionally used biomass fuel, as it is inexpensive and readily available. Countries with lower gross domestic product per capita rely more on biomass fuel than the richer countries. ${ }^{9}$ In Europe, for example, the use has declined to $7 \%$, compared to Africa, where up to $77 \%$ of the population still relies on these traditional fuels. A crosssectional analysis of biomass fuel use in a Malawian periurban area showed that only $3.9 \%$ of the households were exclusively using electricity for their cooking. Most of the households were using either charcoal or firewood. ${ }^{10}$ Similarly, in Zambia, $73 \%$ and $98 \%$ of urban and rural communities, respectively, rely on either charcoal or firewood as fuels. ${ }^{11}$ Surprisingly, despite the ongoing rural electrification programme in Zambia, the use of charcoal increased from $25 \%$ in 2007 to $37 \%$ in $2013-2014 .{ }^{11}$

\section{Biomass smoke and its similarities to cigarette smoke}

There is emerging evidence that long-term exposure to biomass smoke exacerbates, and in some cases causes, disease in humans. The International Agency for Research on Cancer (IARC) classified biomass smoke as a probable carcinogen (group $2 \mathrm{~A})^{12}$ because of the growing evidence of its association with certain cancers and a better understanding of its constituents. Cigarette smoke, containing known carcinogens, is associated with several types of cancer, including those of the upper gastrointestinal tract. ${ }^{13}$ Substances contained in cigarette smoke have been well described, but the content of biomass smoke is more variable and largely depends on the type of biomass being burnt and the temperatures being used. ${ }^{14,15}$ Incomplete combustion of biomass fuel produces several organic and inorganic compounds, the biological effects of which are not fully understood. Table 1 lists carcinogenic substances present in both biomass and cigarette smoke. ${ }^{13,16}$ Among these substances are polycyclic aromatic hydrocarbons $(\mathrm{PAH})$. PAH have been linked to gastrointestinal carcinogenesis. ${ }^{17,18}$ They are primarily produced from the incomplete combustion of organic matter. They can be metabolised to electrophilic forms that adduct to DNA, resulting in misreplication if not repaired. Exposure to wood smoke particulate matter has beeen found to generate more DNA damage than traffic-generated particulate matter, and it is suggested that this observation may result from the high levels of PAH in wood smoke. ${ }^{19}$ Clinical studies have shown that long-term exposure to biomass smoke predisposes to DNA damage and oxidative stress, ${ }^{20,21}$ potential mechanisms of carcinogenesis. In addition, exposure to biomass smoke has been associated with high urinary mutagen content. ${ }^{22}$

\section{Methods}

\section{Source of information}

A literature search was conducted using the electronic database PubMed. We used the search queries "biomass smoke", "wood smoke", "charcoal smoke", "oesophageal cancer", "gastric cancer", and "Africa", each on their own and in combinations, with the timeframe specified to between January 1980 and February 2016, inclusive. Using these key words, we read through 806 titles and abstracts, and 55 original articles were then chosen, as they referred to cancer and biomass smoke. Sixteen articles that did not address the association between biomass smoke exposure or

Figure 1: Flow chart showing the selection of articles from PubMed

806 titles and

abstracts reviewed

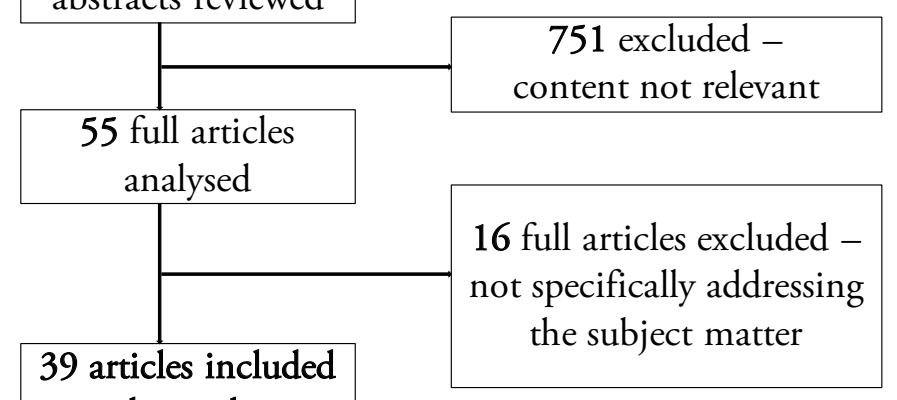

Table 1: Carcinogenic substances present in both cigarette and biomass smoke $\mathrm{e}^{13,16}$

\begin{tabular}{|c|c|c|c|}
\hline Group & Substance & IARC Group & Year of classification \\
\hline \multirow{2}{*}{ Polycyclic hydrocarbons } & Benz[a]anthracene & $2 \mathrm{~A}$ & 1987 \\
\hline & Benzo[a]pyrene & 1 & 2012 \\
\hline \multirow{2}{*}{ Aldehydes } & Formaldehyde & 1 & 2012 \\
\hline & Acetaldehyde & $2 \mathrm{~B}$ & 1999 \\
\hline \multirow[t]{3}{*}{ Aromatics } & Benzene & 1 & 2012 \\
\hline & Arsenic & 1 & 2012 \\
\hline & Beryllium & 1 & 2012 \\
\hline \multirow[t]{3}{*}{ Inorganic toxins } & Nickel & $2 \mathrm{~B}$ & 2012 \\
\hline & Cobalt & $2 \mathrm{~B}$ & 1991 \\
\hline & Lead (inorganic) & $2 \mathrm{~B}$ & 1987 \\
\hline
\end{tabular}

IARC = International Agency for Research on Cancer 
its metabolites on various cancers were excluded, and 39 full articles were then selected based on the specific relevance of their content to the intended subject matter of this review (Figure 1). Articles that presented negative findings were also reviewed.

\section{Results}

Using our search terms, we identified 10 studies that reported an effect of exposure to biomass smoke on UGI cancer (Table 2), all of which reported a significant association. A case-control study of oesophageal cancer patients in Zambia, with age- and sex-matched controls, revealed a significant association with biomass smoke exposure. ${ }^{23}$ Investigators from South Africa reported similar findings, demonstrating a link between SNPs in miR-423 associated with oesophageal cancer and environmental smoke exposure. ${ }^{24}$ Earlier results, also from South Africa, showed an association between biomass smoke exposure and gene polymorphisms linked with the development of oesophageal cancer. ${ }^{25}$ In 2006, Dandara et al. reported a significant association between oesophageal cancer and use of biomass fuel. ${ }^{26}$ In Kenya, at a hospital in which oesophageal cancer was the most common cancer among men, cooking with biomass fuel was found to be a significant risk factor. ${ }^{27}$ In a low-incidence area of Brazil, exposure to biomass smoke was similarly found to be associated with oesophageal cancer. ${ }^{28}$ More recently, a case-control study from Malawi also reported a significant association between biomass smoke exposure and oesophageal cancer. ${ }^{29}$ A large study conducted in Eastern Europe also demonstrated a link between biomass fuel and oesophageal cancer. ${ }^{30}$

Only two relevant studies of gastric cancer, both from outside Africa, were identified. A case-control study done in Peru, involving 96 gastric cancer cases and 96 controls, revealed a significant association between biomass fuel use and gastric cancer. ${ }^{31}$ Data from a study in western Honduras revealed a significant association between gastric cancer and the use of wood stoves, from which biomass smoke is emitted..$^{32}$

\section{Discussion}

This review outlines a collection of evidence in support of an association between biomass smoke exposure and UGI cancers. There is an overlap of established oesophageal and gastric cancer risk factors, and it is therefore likely that biomass smoke could be influencing the development of both types of malignancy. In addition, the review has brought out similarities in the carcinogenic content of cigarette and biomass smoke, with the possibility of common disease associations.

Cancer is an increasing health problem in Africa, partly due to ageing and expanding populations, reduced mortality from infectious disease, and (likely) increased exposure to cancercausing agents. ${ }^{33}$ In Zambia, for example, a retrospective audit of endoscopic records, covering a period of close to four decades, revealed an increase in UGI cancer diagnosis among individuals below the age of 60 years. ${ }^{34}$ Interestingly, the frequency of diagnosis among patients over the age of 60 years remained the same over this period. Similarly, there has been an increase in oesophageal cancer in Ghana, where up to $25 \%$ of the cases are below the age of 50 years. ${ }^{35}$ It remains unclear, however, if these are true increases in incidence or just a reflection of improved diagnostic facilities. We therefore saw the need to conduct a literature review with the intension of contributing to the understanding of UGI cancer development in low-resource settings.

http://dx.doi.org/10.4314/mmj.v29i2.25
Most studies that have linked biomass smoke to oesophageal cancer are from Africa. All show clear associations, but little is understood about the exact pathogenesis. Similar to cigarette smoke, the carcinogens in biomass smoke are inhaled, but could also be swallowed, and the effect on distant tissues suggests systemic spread. UGI cancers are more common in communities of low socioeconomic status, even within the same geographical region., ${ }^{4,36,37}$ Notable deficiencies in these poor communities include clean water, sanitation, good housing, and electricity. Therefore, there is heavy reliance on biomass fuels and, in turn, exposure to smoke and its hazardous constituents. It has been suggested that communicable diseases could be responsible for the higher incidence of UGI cancers in poor communities, but this explanation is far from complete, as many such cancers are not solely caused by infections. It is therefore more likely that other environmental factors, such as biomass smoke exposure, are influencing the development of UGI cancers in these communities. Two of the studies included in this review are from Zambia and Malawi-neighbouring countries with similar populations and socioeconomic environments. Identification of this common problem clearly demonstrates the need for feasible risk reduction strategies applicable to both countries. Finding alternative affordable fuels that could be used in these countries remains challenging.

In Table 2 we went further to summarise studies that have linked biomass smoke exposure to other cancer types. This was done in order to emphasise the understanding that cancers at different sites do sometimes use similar pathogenic mechanisms in their development. In addition, the table shows data from which we could postulate that minimising exposure to biomass smoke might contribute towards a reduction of other cancers as well. The lower gastrointestinal tract is not spared, exemplified by a study from Sweden involving more than 500 colorectal cancer patients reported an association with biomass smoke exposure. ${ }^{38}$

Lastly, this review has demonstrated the need to design studies that would explore the causative link between biomass smoke exposure and UGI cancers. These future studies could also include direct analysis such as air monitoring, or indirect measures with biomarkers.

\section{Conclusions}

In conclusion, we have shown that exposure to biomass smoke is associated with oesophageal and gastric cancer. The similarities of carcinogenic content between cigarette and biomass smoke further supports this theory. If it is correct, then reducing dependence on biomass fuels will have an impact on the occurrence of UGI cancers.

\section{Competing interests}

All authors declare that they have no competing interests related to this work.

\section{References}

1. Fullerton DG, Bruce N, Gordon SB. Indoor air pollution from biomass fuel smoke is a major health concern in the developing world.Trans R Soc Trop Med Hyg. 2008 Sep; 102 (9): 843-51.

2. World Health Organisation, Fact sheet number 292 updated in February 2016. http://www.who.int/mediacentre/factsheets/fs292/en/ [accessed on 8th March 2016].

3. Ferlay J, Soerjomataram I, Ervik M, et al. GLOBOCAN 2012 v1.0, Cancer Incidence and Mortality Worldwide: IARC CancerBase No. 11 [Internet]. Lyon, France: International Agency for Research on Cancer; 2013. Available from: http://globocan.iarc.fr, 18/10/2014 [accessed on 6/07/2015]. 
Table 2: Studies that have evaluated the influence of biomass smoke exposure on cancer risk

Upper gastrointestinal cancers

\begin{tabular}{|c|c|c|c|c|c|}
\hline \multirow{2}{*}{ Study } & \multirow{2}{*}{$\begin{array}{l}\text { Study } \\
\text { location }\end{array}$} & \multirow{2}{*}{$\begin{array}{l}\text { Cancer } \\
\text { type }\end{array}$} & \multicolumn{2}{|c|}{ Sample size } & \multirow{2}{*}{$\begin{array}{c}\text { Odds Ratios (OR), Relative Risk (RR), } \\
\text { 95\% Confidence Intervals (CI), } \\
\text { P-values }\end{array}$} \\
\hline & & & Cases & Controls & \\
\hline Kayamba, $2015^{21}$ & Zambia & Oesophageal & 50 & 50 & $\mathrm{OR}=3.6 ; 95 \% \mathrm{CI}=1.4$ to $9.3 ; \mathrm{P}=0.004$ \\
\hline Wang, $2013^{22}$ & South Africa & $\begin{array}{l}\text { Oesophageal } \\
\text { (gene-environment } \\
\text { interaction) }\end{array}$ & 565 & 1003 & $\begin{array}{c}\mathrm{OR}=1.75 ; 95 \% \mathrm{CI}=1.24 \text { to } 2.46 \\
\mathrm{P}=0.001\end{array}$ \\
\hline $\mathrm{Li}, 2010^{23}$ & South Africa & $\begin{array}{l}\text { Oesophageal } \\
\text { (gene-environment } \\
\text { interaction) }\end{array}$ & 245 & 288 & $\mathrm{OR}=12.1 ; 95 \% \mathrm{CI}=3.26$ to 49 \\
\hline Dandara, 200624 & South Africa & Oesophageal & 63 & 20 & $\begin{array}{c}\mathrm{OR}=15.2 ; 95 \% \mathrm{CI}=8.15 \text { to } 28.2 ; \\
\mathrm{P}=0.0001\end{array}$ \\
\hline Patel, $2013^{25}$ & Kenya & Oesophageal & 159 & 159 & $\begin{array}{c}\mathrm{OR}=2.32 ; 95 \% \mathrm{CI}=1.41 \text { to } 3.84 \\
\mathrm{P}<0.001\end{array}$ \\
\hline Mota, $2013^{26}$ & Brazil & Oesophageal & 99 & 223 & $\begin{array}{c}\mathrm{OR}=4.42 ; 95 \% \mathrm{CI}=2.35 \text { to } 8.32 \\
\mathrm{P}<0.001\end{array}$ \\
\hline Mlombe, $2015^{27}$ & Malawi & Oesophageal & 96 & 180 & $\mathrm{OR}=12.6 ; 95 \% \mathrm{CI}=4.2$ to 37.7 \\
\hline Sapkota, $2013^{28}$ & Multicentre & Oesophageal & 1110 & 186 & $\mathrm{OR}=2.71 ; 95 \% \mathrm{CI}=1.21$ to 6.10 \\
\hline Chirinos, $2012^{31}$ & Peru & Gastric & 96 & 96 & $\mathrm{OR}=5$ \\
\hline Rafkin, $2015^{32}$ & Honduras & Gastric & 814 & 1049 & $\mathrm{OR}=3.54 ; 95 \% \mathrm{CI}=2.18$ to 5.77 \\
\hline
\end{tabular}

\section{Other cancer types}

\begin{tabular}{|c|c|c|c|c|c|}
\hline \multirow{2}{*}{ Study } & \multirow{2}{*}{$\begin{array}{l}\text { Study } \\
\text { location }\end{array}$} & \multirow{2}{*}{$\begin{array}{l}\text { Cancer } \\
\text { Type }\end{array}$} & \multicolumn{2}{|c|}{ Sample size } & \multirow{2}{*}{$\begin{array}{c}\text { Odds Ratios (OR), Relative Risk (RR), } \\
\text { 95\% Confidence intervals (CI), } \\
\text { P-values }\end{array}$} \\
\hline & & & Cases & Controls & \\
\hline $\begin{array}{l}\text { Gerhardsson de } \\
\text { Verdier, } 1992^{38}\end{array}$ & Sweden & $\begin{array}{l}\text { Colon } \\
\text { Rectal }\end{array}$ & 21 & 27 & $\begin{array}{l}\mathrm{RR}=1.2 ; 95 \% \mathrm{CI}=0.6 \text { to } 2.2 \\
\mathrm{RR}=1.9 ; 95 \% \mathrm{CI}=1.0 \text { to } 3.7\end{array}$ \\
\hline Raspanti, $2016^{39}$ & Nepal & Lung & 606 & 606 & $\mathrm{OR}=1.77 ; 95 \% \mathrm{CI}=1.00$ to 3.14 \\
\hline Saikia, 201440 & India & Lung & 272 & 544 & $\begin{array}{c}\mathrm{OR}=3.6 ; 95 \% \mathrm{CI}=1.85 \text { to } 6.98 \\
\mathrm{P}<0.001\end{array}$ \\
\hline Phukan, $2014^{41}$ & India & Lung & 230 & 460 & $\begin{array}{c}\mathrm{OR}=1.5 ; 95 \% \mathrm{CI}=1.01 \text { to } 2.22 \\
\mathrm{P}=0.044\end{array}$ \\
\hline Sloan, $2012^{42}$ & USA & Lung & 277 & 251 & $\begin{array}{c}\mathrm{OR}=2.43 ; 95 \% \mathrm{CI}=1.26 \text { to } 4.67 \\
\mathrm{P}=0.008\end{array}$ \\
\hline $\begin{array}{l}\text { Hernández- } \\
\text { Garduño, } 200443\end{array}$ & Mexico & Lung & 113 & 273 & $\mathrm{OR}=1.9 ; 95 \% \mathrm{CI}=1.1$ to 3.5 \\
\hline Levin, $1988^{44}$ & China & Lung & 738 & 760 & $\mathrm{OR}=1.8 ; 95 \% \mathrm{CI}=1.3$ to 2.5 \\
\hline $\begin{array}{l}\text { Sierra-Torres, } \\
2006^{45}\end{array}$ & Colombia & Cervical & 91 & 92 & $\mathrm{OR}=3.3 ; 95 \% \mathrm{CI}=0.5$ to 22.5 \\
\hline Velema, $2002^{46}$ & Honduras & Cervical & 45 & 241 & $\mathrm{P}=0.022$ \\
\hline Ferrera, $2000^{47}$ & Honduras & Cervical & 99 & 198 & $\mathrm{P}=0.0001$ \\
\hline He, $2015^{48}$ & China & Nasopharyngeal & 1845 & 2275 & $\mathrm{OR}=1.95 ; 95 \% \mathrm{CI}=1.65$ to 2.31 \\
\hline Pintos, $1998^{49}$ & Brazil & $\begin{array}{l}\text { Oral } \\
\text { Pharyngeal } \\
\text { Laryngeal }\end{array}$ & $\begin{array}{l}373 \\
217 \\
194\end{array}$ & 1568 & $\begin{array}{l}\mathrm{OR}=2.73 ; 95 \% \mathrm{CI}=1.8 \text { to } 4.2 \\
\mathrm{OR}=3.82 ; 95 \% \mathrm{CI}=2.0 \text { to } 7.4 \\
\mathrm{OR}=2.34 ; 95 \% \mathrm{CI}=1.2 \text { to } 4.7\end{array}$ \\
\hline Sapkota, $2008^{50}$ & India & Hypopharyngeal & 799 & 1062 & $\mathrm{OR}=1.62 ; 95 \% \mathrm{CI}=1.14$ to 2.32 \\
\hline Greenop, $2015^{51}$ & Australia & $\begin{array}{l}\text { Childhood brain } \\
\text { tumours }\end{array}$ & 306 & 950 & $\mathrm{OR}=1.51 ; 95 \% \mathrm{CI}=1.05$ to 2.15 \\
\hline
\end{tabular}

While this review is focused on upper gastrointestinal cancers in Africa, studies from other geographical locations and reporting about other cancer types are included to illustrated similarities. 
4. Laryea DO, Awuah B, Amoako YA, et al. Cancer incidence in Ghana, 2012: evidence from a population-based cancer registry. BMC Cancer. 2014. 14:362

5. Sitas F, Parkin M, Chirenje Z, et al. In: Jamison DT, Feachem RG, Makgoba MW, et al., editors. Disease and Mortality in Sub-Saharan Africa. 2nd edition. Washington (DC): World Bank; 2006. Chapter 20. Available from: http://www.ncbi.nlm.nih.gov/books/NBK2293/ [accessed on 10th March 2016].

6. American Cancer Society. Cancer in Africa. 2011, http://www.cancer. org/acs/groups/content/@epidemiologysurveilance/documents/ document/acspc-031574.pdf [accessed on 21st March 2016].

7. Bayo S, Parkin DM, Koumaré AK, et al. Cancer in Mali, 1987-1988. Int J Cancer. 1990 Apr 15; 45(4): 679-84.

8. Wabinga HR, Parkin DM, Wabwire-Mangen F, et al. Trends in cancer incidence in Kyadondo County, Uganda, 1960-1997. Br J Cancer. 2000 May; 82(9):1585-92.

9. Bonjour S, Adair-Rohani H, Wolf J, et al. Solid fuel use for household cooking: country and regional estimates for 1980-2010. Environ Health Perspect. 2013. 121(7): 784-90

10. Piddock KC, Gordon SB, Ngwira A, et al. A cross-sectional study of household biomass fuel use among a periurban population in Malawi. Ann Am Thorac Soc. 2014 Jul; 11 (6): 915-24.

11. Central Statistical Office (CSO) [Zambia], Ministry of Health $(\mathrm{MOH})$ [Zambia], and ICF International. Zambia Demographic and Health Survey 2013-14. Rockville, Maryland, USA: Central Statistical Office, Ministry of Health, and ICF International, 2014.

12. Straif K, Baan R, Grosse Y, et al. WHO International Agency for Research on Cancer Monograph Working Group. Carcinogenicity of household solid fuel combustion and of high-temperature frying. Lancet Oncol. 2006 Dec; 7 (12): 977-8.

13. International Agency for Research on Cancermonographs on the evaluation of carcinogenic risks to humans. http://monographs.iarc.fr/ ENG/Monographs/vol83/mono83.pdf [accessed on 18th April 2016]

14. Chaemsai S, Kunanopparat T, Srichumpuang J, et al. Reduction of the polycyclic aromatic hydrocarbon $(\mathrm{PAH})$ content of charcoal smoke during grilling by charcoal preparation using high carbonisation and a preheating step. Food Addit Contam Part A Chem Anal Control Expo Risk Assess. 2016 Mar;33(3):385-90.

15. Fine PM, Cass GR, Simoneit BR. Chemical characterization of fine particle emissions from fireplace combustion of woods grown in the northeastern United States. Environ Sci Technol. 2001,35(13): 2665-75.

16. International Agency for Research on Cancer. List of classifications, volumes 1-115. http://monographs.iarc.fr/ENG/Classification/latest_ classif.php [accessed 18th April 2016]

17. Abedi-Ardekani B, Kamangar F, Hewitt SM, Hainaut P, Sotoudeh M, Abnet CC, Taylor PR, Boffetta P, Malekzadeh R, Dawsey SM. Polycyclic aromatic hydrocarbon exposure in oesophageal tissue and risk of oesophageal squamous cell carcinoma in north-eastern Iran. Gut. 2010 Sep;59(9):1178-83. doi: 10.1136/gut.2010.210609.

18. Kamangar F, Schantz MM, Abnet CC, Fagundes RB, Dawsey SM. High levels of carcinogenic polycyclic aromatic hydrocarbons in mate drinks. Cancer Epidemiol Biomarkers Prev. 2008 May;17(5):1262-8. doi: 10.1158/1055-9965.EPI-08-0025.

19. Danielsen PH, Loft S, Kocbach A, et al. Oxidative damage to DNA and repair induced by Norwegian wood smoke particles in human A549 and THP-1 cell lines. Mutat Res. 2009 Mar 31; 674(1-2): 116-22.

20. Mukherjee B, Dutta A, Roychoudhury S, et al. Chronic inhalation of biomass smoke is associated with DNA damage in airway cells: involvement of particulate pollutants and benzene. J Appl Toxicol. 2013 Apr; 33 (4):281-9.

21. Mondal NK, Bhattacharya P, Ray MR. Assessment of DNA damage by comet assay and fast halo assay in buccal epithelial cells of Indian women chronically exposed to biomass smoke. Int J Hyg Environ Health. 2011 Jul; 214 (4): 311-8.

22. Long AS, Lemieux CL, Yousefi P, et al. Human urinary mutagenicity after wood smoke exposure during traditional temazcal use. Mutagenesis. 2014 Sep; 29(5):367-77.

http://dx.doi.org/10.4314/mmj.v29i2.25
23. Kayamba V, Bateman AC, Asombang AW, et al. HIV infection and domestic smoke exposure, but not human papillomavirus, are risk factors for oesophageal squamous cell carcinoma in Zambia: a case-control study. Cancer Med. 2015 Apr; 4 (4): 588-95.

24. Wang Y, Vogelsang M, Schäfer G, et al. MicroRNA polymorphisms and environmental smoke exposure as risk factors for oesophageal squamous cell carcinoma. PLoS One. 2013 Oct 21;8(10): e78520.

25. Li D, Dandara C, Parker MI. The 341C/T polymorphism in the GSTP1 gene is associated with increased risk of oesophageal cancer. BMC Genet. 2010 Jun 11; 11: 47.

26. Dandara C, Li DP, Walther G, et al. Gene-environment interaction: the role of SULT1A1 and CYP3A5 polymorphisms as risk modifiers for squamous cell carcinoma of the oesophagus. Carcinogenesis. 2006 Apr; 27(4):791-7.

27. Patel K, Wakhisi J, Mining S, et al. Oesophageal Cancer, the Topmost Cancer at MTRH in the Rift Valley, Kenya, and Its Potential Risk Factors. ISRN Oncol. 29; 2013:503249.

28. Mota OM, Curado MP, Oliveira JC, et al. Risk factors for oesophageal cancer in a low-incidence area of Brazil. Sao Paulo Med J. 2013; 131(1): 27-34.

29. Mlombe YB, Rosenberg NE, Wolf LL, Dzamalala CP, Chalulu K, Chisi J, Shaheen NJ, Hosseinipour MC, Shores CG. Environmental risk factors for oesophageal cancer in Malawi: A case-control study. Malawi Med J. 2015 Sep;27(3):88-92

30. Sapkota A, Zaridze D, Szeszenia-Dabrowska N, Mates D, Fabiánová E, Rudnai P, Janout V, Holcatova I, Brennan P, Boffetta P, Hashibe M. Indoor air pollution from solid fuels and risk of upper aerodigestive tract cancers in central and eastern Europe. Environ Res. 2013 Jan;120:90-5. doi: 10.1016/j.envres.2012.09.008.

31. Chirinos JL, Carbajal LA, Segura MD, et al. Gastric cancer: epidemiologic profile 2001-2007 in Lima, Peru. Rev Gastroenterol Peru. 2012 Jan-Mar; 32(1):58-64.

32. Rifkin S, Dominguez R, Suazo L, Mera R, Morgan DR. Role of Wood Stove (Fogón) Use and the Effects of Heterocyclic Amines (HCAs) in Gastric Cancer in Central America. Gastroenterology 2015; 148 (4): S-764.

33. Parkin DM, Bray F, Ferlay J, et al. Cancer in Africa 2012. Cancer Epidemiol Biomarkers Prev. 2014. 23(6): 953-66.

34. Kayamba V, Sinkala E, Mwanamakondo S, Soko R, Kawimbe B, Amadi B, Zulu I, Nzaisenga JB, Banda T, Mumbwe C, Phiri E, Munkonge P, Kelly P. Trends in upper gastrointestinal diagnosis over four decades in Lusaka, Zambia: a retrospective analysis of endoscopic findings. BMC Gastroenterol. 2015 Oct 6; 15:127.

35. Tettey M, Edwin F, Aniteye E, et al. The changing epidemiology of oesophageal cancer in sub-Saharan Africa - the case of Ghana. Pan Afr Med J. 2012; 13:6.

36. Gammon MD, Schoenberg JB, Ahsan H, et al. Tobacco, alcohol, and socioeconomic status and adenocarcinomas of the esophagus and gastric cardia. J Natl Cancer Inst 1997; 89: 1277-84.

37. Brewster DH, Fraser LA, McKinney PA, et al. Socioeconomic status and risk of adenocarcinoma of the oesophagus and cancer of the gastric cardia in Scotland. Br J Cancer. 2000 Aug; 83 (3): 387-90.

38. Gerhardsson de Verdier M, Plato N, Steineck G, et al. Occupational exposures and cancer of the colon and rectum. Am J Ind Med. 1992; 22(3): 291-303.

39. Raspanti GA, Hashibe M, Siwakoti B, et al. Household air pollution and lung cancer risk among never-smokers in Nepal. Environ Res. 2016 Feb 10; 147:141-145.

40. Saikia BJ, Das M, Sharma SK, et al. Association of a p53 codon 72 gene polymorphism with environmental factors and risk of lung cancer: a case control study in Mizoram and Manipur, a high incidence region in North East India. Asian Pac J Cancer Prev. 2014; 15(24): 10653-8.

41. Phukan RK, Saikia BJ, Borah PK, et al. Role of household exposure, dietary habits and glutathione S-Transferases M1, T1 polymorphisms in susceptibility to lung cancer among women in Mizoram India. Asian Pac J Cancer Prev. 2014; 15(7): 3253-60. 
42. Sloan CD, Andrew AS, Gruber JF, et al. Indoor and Outdoor Air Pollution and Lung Cancer in New Hampshire and Vermont. Toxicol Environ Chem. 2012 Jan 1; 94(3).

43. Hernández-Garduño E, Brauer M, Pérez-Neria J, et al. Wood smoke exposure and lung adenocarcinoma in non-smoking Mexican women. Int J Tuberc Lung Dis. 2004 Mar; 8 (3): 377-83.

44. Levin LI, Zheng W, Blot WJ, et al. Occupation and lung cancer in Shanghai: a case-control study. Br J Ind Med. 1988 Jul; 45 (7):450-8.

45. Sierra-Torres CH, Arboleda-Moreno YY, Orejuela-Aristizabal L. Exposure to wood smoke, HPV infection, and genetic susceptibility for cervical neoplasia among women in Colombia. Environ Mol Mutagen. 2006 Aug; 47 (7):553-61.

46. Velema JP, Ferrera A, Figueroa M, et al. Burning wood in the kitchen increases the risk of cervical neoplasia in HPV-infected women in Honduras. Int J Cancer. 2002 Feb 1; 97(4): 536-41.

47. Ferrera A, Velema JP, Figueroa M, et al. Co-factors related to the causal relationship between human papillomavirus and invasive cervical cancer in Honduras. Int J Epidemiol. 2000 Oct; 29 (5): 817-25.
48. He YQ, Xue WQ, Shen GP, et al. Household inhalants exposure and nasopharyngeal carcinoma risk: a large-scale case-control study in Guangdong, China. BMC Cancer. 2015 Dec 29; 15(1): 1022.

49. Pintos J, Franco EL, Kowalski LP, et al. Use of wood stoves and risk of cancers of the upper aero-digestive tract: a case-control study. Int J Epidemiol. 1998 Dec; 27 (6): 936-40.

50. Sapkota A, Gajalakshmi V, Jetly DH, et al. Indoors air pollution from solid fuels and risk of hypopharyngeal/laryngeal and lung cancers: a multicentric case-control study from India. Int J Epidemiol. 2008 Apr;37(2):321-8.

51. Greenop KR, Hinwood AL, Fritschi L, et al. Vehicle refuelling, use of domestic wood heaters and the risk of childhood brain tumours: Results from an Australian case-control study. Pediatr Blood Cancer. 2015 Feb;62(2):229-234. 